\title{
IKLIM ORGANISASI DAN KUALITAS KEHIDUPAN KERJA KARYAWAN
}

\author{
Imam Aryansah \& Erika Setyanti Kusumaputri \\ Program Studi Psikologi \\ Universitas Islam Negeri Sunan Kalijaga Yogyakarta \\ J1. Marsda Adisucipto, Yogyakarta 55281 \\ imamaryansah@gmail.com
}

\begin{abstract}
This study aims to test empirically the relationship between organizational climate and the quality of work life of employees at PT Aseli Dagadu Djokdja. The sample is the whole employees of PT. Aseli Dagadu Djokdja. Data were collected through organization climate scale and quality of work life scale. Product Moment Correlation was used as analysis technique. Based on result of data analysis, there is positive correlation between organizational climate and PT. Aseli Dagadu Djokdja employee's quality of work life. The effective contribution of organization climate to quality of work life was $48,4 \%$.
\end{abstract}

Keywords : organizational climate, quality of work life.

\begin{abstract}
Abstrak
Penelitian ini bertujuan untuk menguji secara empirik hubungan antara iklim organisasi dengan kualitas kehidupan kerja karyawan pada PT Aseli Dagadu Djokdja. Sampel yang digunakan merupakan keseluruhan karyawan PT. Aseli Dagadu Djokdja. Data dikumpulkan dengan skala iklim organisasi dan skala kualitas kehidupan kerja. Teknik analisis yang digunakan adalah korelasi product moment. Berdasarkan hasil analisis data dengan menggunakan product moment diperoleh hasil bahwa ada hubungan positif antara iklim organisasi dengan kualitas kehidupan kerja karyawan PT Aseli Dagadu Djokdja. Adapun sumbangan efektif variabel iklim organisasi pada kualitas kehidupan kerja adalah sebesar $48,4 \%$, hal ini menunjukkan bahwa iklim organisasi menyumbang $48,4 \%$ terhadap kualitas kehidupan kerja.
\end{abstract}

Kata kunci : iklim organisasi, kualitas kehidupan kerja. 


\section{Pendahuluan}

Perkembangan global menghadapkan industri kreatif pada persaingan yang ketat untuk menarik minat konsumen dengan produk unik dan kreatif perusahaan. Hill dan Jones (Riady, 2009) menyatakan bahwa perkembangan global membuat perusahaan untuk bersaing ketat memunculkan keunggulan dalam efisiensi, keunggulan dalam mutu, keunggulan dalam inovasi (proses dan produk), serta keunggulan dalam pelayanan konsumen. Perusahaan tidak hanya dituntut bersaing pada strategi penawaran produk perusahaan, tetapi juga kualitas kinerja perusahaan, yaitu bagaimana perusahaan dapat memberikan pelayanan yang baik dan produk yang bermutu terhadap konsumen. Menciptakan keungulan dibanding perusahaan lainnya untuk mendapatkan kepuasan konsumen yang hasilnya akan memberikan kontribusi positif terhadap perusahaan.

Sumber daya manusia merupakan faktor utama yang dapat menentukan eksistensi dan bonafiditas suatu perusahaan. Perusahaan membutuhkan sumber daya manusia yang mampu berprestasi, memiliki motivasi tinggi, dan mampu bekerja sebaik mungkin demi kepentingan perusahaan. Terlebih pada perusahaan industri kreatif, sumber daya manusia merupakan ujung tombak keberhasilan perusahaan mempertahankan eksistensinya dalam inovasi-inovasi keunggulan. Kinerja dari sumber daya manusia akan berdampak pada penilaian konsumen terhadap kualitas perusahaan tersebut.

Oleh karena itu, peningkatan akan kualitas sumber daya manusia merupakan suatu keharusan demi tercapainya tujuan perusahaan. Banyak faktor yang mempengaruhi peningkatan kualitas sumber daya manusia. Zin (2004) menyebutkan bahwa ada tujuh dimensi di dalam kualitas kehidupan kerja yang diharapkan dapat meningkatkan kualitas sumber daya manusia, yaitu partisipasi dalam pemecahan masalah, sistem imbalan yang inovatif, lingkungan kerja yang kondusif, pengembangan diri, kepemimpinan, integrasi dan relevansi sosial. Penjelasan di atas menyiratkan bahwa kualitas kehidupan kerja adalah cara yang tepat untuk meningkatkan kualitas sumber daya manusia dalam perusahaan. Melalui proses-proses tersebut, sumber daya manusia (karyawan) diharapkan akan lebih memaksimalkan tanggung jawab atas pekerjaan mereka.

Kualitas kehidupan kerja menurut Dessler (1992) merupakan suatu keadaan yang dirasakan oleh karyawan untuk dapat memenuhi kebutuhan penting mereka dengan bekerja dalam organisasi. Cascio (1992) menyatakan kualitas kehidupan kerja sebagai persepsi karyawan bahwa mereka ingin merasa aman, secara relatif merasa puas dan mendapat kesempatan berkembang selayaknya manusia. Menurut Llyod (Moorhead dan Griffin, 1995) kualitas kehidupan kerja merupakan sejauh mana para pekerja dapat memenuhi kebutuhan-kebutuhan pribadi yang penting melalui 
pengalaman mereka dalam organisasi dimana mereka bekerja. Kualitas kehidupan kerja merupakan suatu keadaan terpenuhinya kebutuhan-kebutuhan karyawan, adanya kesempatan bagi karyawan untuk turut berperan menentukan cara bekerja dan sumbangan yang dapat diberikan karyawan pada organisasi (Zin, 2004). Pada kesimpulannya, kualitas kehidupan kerja merupakan cerminan perasaan karyawan terhadap pekerjaannya, termasuk dampak dari pekerjaaan tersebut terhadap kesejahteraan karyawan (Umstot, dalam Idrus,2006).

Kualitas kehidupan kerja merupakan masalah utama yang patut mendapat perhatian dari suatu perusahaan. Hal ini merujuk pada pemikiran bahwa kualitas kehidupan kerja dipandang mampu untuk meningkatkan peran serta dan sumbangan para anggota atau karyawan terhadap perusahaan (Husnawati, 2006). Wether dan Davis (1996) mengemukakan bahwa keberhasilan penciptaan kualitas kehidupan kerja dalam suatu perusahaan memberi pengaruh terhadap beberapa hal yang spesifik dalam diri karyawan, yaitu kepuasan kerja, motivasi, dan keterlibatan karyawan. Bila kualitas kehidupan kerja pada karyawan menunjukkan prosentasi yang tinggi, maka akan menimbulkan dampak positif bagi perusahaan, seperti meningkatnya produktivitas, kualitas kerja, dan menurunkan tingkat absensteeism (kemangkiran) dan turnover (perputaran karyawan) (Riggio, 1990). Hal tersebut dapat diartikan bahwa kualitas kehidupan kerja karyawan yang baik merupakan harapan bagi semua perusahaan, sebab kualitas kehidupan kerja karyawan ini pada akhirnya diharapkan dapat meningkatkan produktivitas perusahaan secara keseluruhan.

Jewell dan Siegel (1998) menyatakan bahwa baik atau tidaknya kualitas kehidupan kerja karyawan, mengacu pada pengaruh situasi kerja keseluruhan terhadap seorang individu. Whether dan Davis (1996) menjelaskan kualitas kehidupan kerja dipengaruhi oleh beberapa faktor yaitu supervisi, kondisi kerja, gaji, tunjangan, dan desain pekerjaan.

Banyak peneliti yang menguraikan berbagai faktor-faktor yang mempengaruhi kualitas kehidupan kerja. Namun, pada penelitian ini iklim organisasi menjadi variabel yang mempengaruhi kualitas kehidupan kerja. Hal tersebut, didasarkan pada penelitian Dhar (2008) menunjukkan bahwa tantangan yang karyawan hadapi dalam bekerja dan kondisi dimana karyawan bekerja merupakan faktor potensial yang berdampak pada kualitas kehidupan kerja. Senada dengan penelitian di atas, Luthan (2006) juga mengungkapkan bahwa lingkungan kerja dan iklim organisasi memberikan pengaruh yang signifikan terhadap karyawan. Lingkungan yang menciptakan milieu kultural dan sosial tempat berlangsungnya kerja atau yang dikenal dengan iklim organisasi akan menentukan kualitas kehidupan kerja seorang karyawan (Idrus, 2006). 
Iklim organisasi menurut Wirawan (2008) adalah persepsi anggota organisasi mengenai apa yang ada atau terjadi di lingkungan internal organisasi secara rutin, yang mempengaruhi sikap dan perilaku, serta kinerja anggota organisasi. Brown dan Leigh (1996) menyatakan bahwa iklim organisasi adalah keadaan lingkungan organisasi yang dirasakan oleh karyawan yang mengarah pada aspek-aspek seperti: keamanan psikologis dan kebermaknaan psikologis lingkungan kerja. Keamanan psikologis meliputi kemampuan pikiran dan perasaan karyawan untuk menunjukkan dan mengembangkan diri karyawan tanpa rasa takut terhadap konsekuensi negatif pada citra diri, status dan kelangsungan karirnya. Kebermaknaan psikologis merupakan perasaan karyawan bahwa mereka memperoleh pengembalian dari investasi energi fisik, kognitif, dan emosional yang mereka lakukan dalam bekerja. Karyawan merasa bahwa kerja mereka bermakna, jika mereka merasa bahwa pekerjaan tersebut menantang, bermanfaat dan menghasilkan imbalan. Penilaian individu terhadap situasi organisasi berbeda antara karyawan yang satu dengan karyawan yang lain, yang disebabkan oleh perbedaan dalam kemampuan, nilai-nilai, dan kebiasaan-kebiasaan karyawan yang harus disesuaikan dengan budaya organisasi, perbedaan kontribusi karyawan terhadap organsasi, dan perbedaan dalam gaya manajemen.

Iklim organisasi yang baik dalam bekerja menimbulkan kenyamanan, saling menghormati, dan kebersamaan dalam bekerja. Idealnya, dengan sendirinya jika orang telah merasa nyaman dengan pekerjaannya, maka akan meningkatkan kualitas kehidupan kerjanya.Namun demikian, banyak karyawan yang merasa nyaman dengan iklim bekerjanya tetapi banyak juga karyawan yang melakukan berbagai tindakan indisipliner tanpa adanya motivasi untuk berkembang dan meningkatkan produktivitas kerja. Gambaran kasus di atas peneliti temukan pada beberapa karyawan PT Aseli dagadu djokdja. Hasil tersebut menunjukkan bahwa proses bekerja di perusahaan bernuansa kekeluargaan. Semua karyawan memiliki hubungan yang baik dan saling menghargai terhadap posisi dan proses bekerjanya. Hal tersebut menunjukkan iklim organisasi yang baik. Akan tetapi pekerjaan yang monoton, tidak adanya tantangan akan menghilangkan semangat kerja karyawan. Hal ini sering dialami oleh beberapa karyawan, waktu bekerja lebih banyak dihabiskan untuk ngobrol bersama rekan kerja. Atau, ada beberapa karyawan yang menunjukkan perilaku sering melamun, terlihat lemas dan tidak bersemangat. Kondisi tersebut merupakan gejala kualitas kehidupan kerja yang rendah yang disebutkan oleh Jewell dan Siegel (1998) yaitu kebosanan dan kehilangan semangat kerja. 


\section{Metode Penelitian}

Sampel penelitian adalah karyawan PT Aseli Dagadu Djokdja yang telah bekerja dalam perusahaan minimal 3 bulan, dan terikat secara sah dalam perjanjian kerja baik tetap maupun kontrak dengan perusahaan. Adapun pengambilan sampel menggunakan teknik purposive sampling yaitu dengan memilih subjek berdasar karakteristik yang telah ditentukan di atas.

Dalam penelitian ini, metode yang dipergunakan adalah metode skala. Skalakualitas kehidupan kerja yaitu berupa skalayang disusun peneliti denganmemodifikasi dari indikator perilaku yang dikembangkan oleh Zin (2004). Skala ini terdiri dari 56 aitem yang disusun untuk mengukur ketujuh dimensi kualitas kehidupan kerja sebagai berikut:

Tabel 1

Indikator skala kualitas kehidupan kerja

\begin{tabular}{|c|c|c|}
\hline No & Dimensi & Indikator \\
\hline \multirow[t]{2}{*}{1} & Pertumbuhan dan & $\begin{array}{l}\text { Karyawan diberi kesempatan untuk menggunakan } \\
\text { keterampilan kerjanya }\end{array}$ \\
\hline & pengembangan & $\begin{array}{l}\text { Karyawan diberi kesempatan untuk meningkatkan } \\
\text { keterampilan kerjanya }\end{array}$ \\
\hline 2 & Partisipasi & $\begin{array}{l}\text { Kesempatan karyawan yang dilibatkan dalam } \\
\text { pengambilan keputusan/penyelesaian masalah }\end{array}$ \\
\hline 3 & Lingkungan fisik & $\begin{array}{l}\text { jam kerja yang berlaku sesuai bagi karyawan } \\
\text { Karyawan merasakan lingkungan kerja yang nyaman }\end{array}$ \\
\hline 4 & Atasan & $\begin{array}{l}\text { Karyawan dan atasan memiliki hubungan yang baik } \\
\text { dan saling pengertian }\end{array}$ \\
\hline 5 & Gaji dan benefit & $\begin{array}{l}\text { Karyawan dapat memuaskan kebutuhannya sesuai } \\
\text { dengan standar hidup karyawan yang bersangkutan } \\
\text { dan sesuai dengan standar pengupahan yang berlaku }\end{array}$ \\
\hline 6 & Relevansi sosial & $\begin{array}{l}\text { Karyawan mampu membuat hubungan yang sinergis } \\
\text { antara pekerjaan dan aspek kehidupan yang lainnya }\end{array}$ \\
\hline 7 & Integrasi sosial & $\begin{array}{l}\text { Sesama rekan kerja memiliki hubungan dan } \\
\text { kekompakan dalam bekerja }\end{array}$ \\
\hline
\end{tabular}

Skala Iklim organisasi yang digunakan peneliti mengacu pada dimensi-dimensi iklim organisasi yang dikemukakan oleh Brown dan Leigh (1996) yang menggambarkan karakteristik penting yang ada dalam pekerjaan, yang menimbulkan respon persepsi terhadap lingkungan organisasi. Skala ini terdiri dari 48 aitem yang 
disusun untuk mengukur keenam variabel iklim organisasi sebagai berikut:

Tabel 2

Indikator skala Iklim Organisasi

\begin{tabular}{|c|c|c|}
\hline Dimensi & & Indikator \\
\hline \multirow[t]{3}{*}{$\begin{array}{l}\text { Keamanan } \\
\text { psikologis }\end{array}$} & $\begin{array}{l}\text { a) Dukungan } \\
\text { manajemen }\end{array}$ & $\begin{array}{l}\text { Karyawan merasakan kepercayaan dan } \\
\text { memperoleh dukungan dalam perusahaan } \\
\text { terhadap kinerjanya }\end{array}$ \\
\hline & b) Kejelasan & $\begin{array}{l}\text { Persepsi karyawan atas kejelasan aturan } \\
\text { dan norma yang berlaku dalam perusahaan }\end{array}$ \\
\hline & c) Ekspresi diri & $\begin{array}{l}\text { Karyawan merasa bertanggung jawab atas } \\
\text { pekerjaannya sendiri }\end{array}$ \\
\hline \multirow{2}{*}{\multicolumn{2}{|c|}{$\begin{array}{l}\text { Kebermaknaan a) } \begin{array}{l}\text { Makna kontribu } \\
\text { psikologis }\end{array} \text { yang dirasakan }\end{array}$}} & $\begin{array}{l}\text { i Perasaan bangga anggota terhadap } \\
\text { organisasinya }\end{array}$ \\
\hline & & $\begin{array}{l}\text { Persepsi karyawan terhadap derajat keloyalan } \\
\text { anggota organisasi terhadap pencapaian tujuan } \\
\text { organisasi }\end{array}$ \\
\hline & b) Penghargaan & $\begin{array}{l}\text { Anggota organisasi merasa dihargai jika dapat } \\
\text { menyelesaikan tugas secara baik }\end{array}$ \\
\hline & c) Tantangan & $\begin{array}{l}\text { Persepsi karyawan terhadap tingkat tekanan } \\
\text { yang diberlakukan organisasi untuk } \\
\text { meningkatkan kinerja karyawan }\end{array}$ \\
\hline
\end{tabular}

Validitas yang digunakan dalam penelitian ini adalah validitas isi (content validity). Menurut Azwar (2011) validitas isi yakni penilaian terhadap sejauhmana butir atau aitem dalam skala mencakup kawasan isi yang hendak diukur dalam skala tersebut. Validitas isi ini diestimasi lewat pengujian terhadap isi tes dengan analisis rasional atau lewat professional judgment (pendapat profesional).

Validitas isi dapat dicapai dengan membuat blue print alat ukur berdasarkan aspek-aspek variabel yang hendak diukur dan membagi aitem pernyataan antara pernyataan favorable dan aitem pernyataan unfavorable, antara aitem pernyataan aspek yang satu dengan aitem pernyataan aspek yang lainnya, dengan jumlah yang sama banyak dan seimbang. Validitas isi ini juga diperoleh dengan cara membuat alat ukur bersama seorang yang ahli di dalam bidang pengukuran sehingga aitem-aitem yang dibuat akan mewakili atribut atau indikator.

Proses selanjutnya adalah proses analisis aitem untuk menyeleksi aitem-aitem mana yang dapat digunakan untuk menyusun alat ukur penelitian. Proses seleksi aitem dilakukan dengan menggunakan parameter daya beda. Parameter daya beda berupa 
koefisien korelasi aitem-total yang memperlihatkan kesesuaian fungsi aitem dengan fungsi skala dalam mengungkap perbedaan individual (Azwar, 2003). Inilah yang disebut oleh Suryabrata (2005) sebagai item validity (validitas pernyataan) yaitu pernyataanpernyataan yang ada dalam skala memiliki kesamaan dalam mengukur sesuatu.

Pengujian terhadap daya diskriminasi ini kemudian akan menghasilkan koefesien korelasi aitem-total (corrected item-total corelation) dan dengan melihat besarnya koefisien korelasi aitem-total ini, dilakukan proses pemilihan aitem-aitem skala. Menurut Azwar (2003), sebagai pemilihan item berdasarkan korelasi item total, biasanya digunakan batasan $\mathrm{r}^{---}{ }_{\mathrm{ix}} \geq 0,30$. Semua item yang mencapai koefisien korelasi minimal 0,30 daya pembedanya dianggap memuaskan.

Tabel 3

Reliabilitas skala

\begin{tabular}{lcc}
\hline Skala & Jumlah butir shahih & Koefisien alpha \\
\hline Skala Kualitas Kehidupan Kerja & 34 & 0.884 \\
Skala Iklim Organisasi & 32 & 0.925 \\
\hline
\end{tabular}

Sesuai dengan hipotesis yang diajukan dan berdasarkan identitas variabel penelitian, jenis data, dan tujuan penelitian, yaitu untuk menguji secara empirik hubungan antara iklim organisasi dengan kualitas kehidupan kerja karyawan pada PT Aseli Dagadu Djokdja, maka statistik yang digunakan adalah teknik korelasi product moment.

\section{Hasil dan Pembahasan}

Hasil penelitian menunjukkan bahwa ada hubungan positif yang sangat signifikan antara iklim organisasi dengan kualitas kehidupan kerja karyawan PT Aseli Dagadu Djokdja.Berdasarkan hasil tersebut, hipotesis yang diajukan pada penelitian ini diterima, ditunjukan dengan koefisien korelasi (rxy) sebesar 0.696 dengan $\mathrm{p}=$ 0.000 ( $\mathrm{p}<0.05$ ).Hal ini mengindikasikan bahwa semakin positif iklim organisasi maka semakin tinggi kualitas kehidupan kerja pada karyawan. Sebaliknya, semakin negatif iklimorganisasi maka semakin rendah kualitas kehidupan kerja pada karyawan.

Kualitas kehidupan kerja adalah kesejahteraan fisik dan psikologis karyawan dalam bekerja yang secara relatif merasa puas dan mendapat kesempatan mampu tumbuh dan berkembang selayaknya manusia. Riady (2009) menekankan bahwa paradigma kualitas kehidupan kerja berfokus pada persoalan seperti motivasi, keterlibatan karyawan dan kepuasan kerja. 
Kualitas kehidupan kerja dapat meningkatkan efisiensi dan efektifitas organisasi dengan memberikan kontribusi terhadap transformasi sumberdaya, inovasi, dan daya adaptasi. Bila kualitas kehidupan kerja pada karyawan menunjukkan prosentasi yang tinggi, makaakanmenimbulkan dampak positif bagi organisasi, seperti meningkatnya produktivitas, kualitas kerja, dan menurunkan tingkat absenteeism dan turn over (Riggio, 1990). Namun sebaliknya bila kualitas kehidupan kerja karyawan pada perusahaan rendah, maka tidak akan terjadi peningkatan produktivitas kerja karyawan. Kualitas kehidupan kerja tentu saja merupakan tujuan bagi semua perusahaan dan institusi yang mempekerjakan karyawan, sebab kualitas kehidupan kerja karyawan ini pada akhirnya diharapkan dapat meningkatkan produktivitas perusahaan secara keseluruhan.

Data hasil penelitian ini membuktikan bahwa salah satu faktor yangmempengaruhi kualitas kehidupan kerja pada karyawan PT Aseli Dagadu Djokdja adalah iklim organisasi. Perbedaan persepsi terhadap iklim organisasi yang disebabkan dari beberapa kondisi (diantaranya; bagaimana setiap orang mempersepsi aturan-aturan, kebijakan-kebijakan, dan prosedur-prosedur organisasi terutama masalah-masalah yang berhubungan dengan personalia, distribusi imbalan, gaya komunikasi, cara-cara yang digunakan untuk memotivasi, teknik-teknik dan tindakan pendisiplinan, interaksi antara menajemen dan kelompok, interaksi antara kelompok, perhatian pada permasalahan yang dimiliki karyawan dari waktu ke waktu) dengan sendirinya memberi pengaruh yang berbeda pada kualitas kehidupan kerja. Persepsi positif karyawan terhadap lingkungan kerjanya dapat menimbulkan perasaan senang, gembira dan penuh percaya diri terhadap pekerjaan dan tanggung jawabnya, oleh karena itu persepsi tersebut dapat mempengaruhi kualitas kehidupan kerja karyawan. Sebaliknya, jika karyawan memiliki persepsi negatif terhadap lingkungan organisasinya, maka mereka akan merasakan pekerjaan sebagai suatu beban, yang akhirnya akan menurunkan kualitas kehidupan kerja mereka.

Hasil penelitian ini mendukung pendapat dari Dessler (1992) yang menyatakan bahwa kemampuan untuk mewujudkan kualitas kehidupan kerja pada diri sendiri bergantung pada apakah terdapat adanya perlakuan yang adil dan suportif para pegawai, kesempatan bagi tiap pegawai untuk menggunakan kemampuan secara penuh, kesempatan untuk mengembangkan diri, komunikasi terbuka dengan saling mempercayai diantara rekan kerja, kesempatan bagi semua pegawai untuk berperan secara aktif dalam pengambilan keputusan penting yang melibatkan pekerjaan mereka, kompensasi yang cukup adil dan lingkungan yang sehat dan aman. Kesemua itu didapat dari bagaimana karyawan mempersepsinya berdasar kebutuhan dan sistem 
nilai yang ada dalam masing-masing diri karyawan. Jika kondisi iklim organisasi sebagaimana dipersepsi oleh karyawan baik, maka menurut Umstot (Idrus,2006) akan menghasilkan 3 katagori psychological states, yaitu (1) kebermaknaan pekerjaan yang dialami; (2) tanggungjawab hasil pekerjaan yang dialami; (3) pengetahuan dari hasil nyata pekerjaan yang dilaksanakan. Bila ketiga kondisi psikologis ini muncul, maka sejumlah kepribadian dan hasil pekerjaan positif dapat diprediksikan. Orang akan merasa lebih baik dengan pekerjaan mereka dan lebih menyukai pekerjaan yang berkualitas tinggi. Dengan sendirinya jika orang telah merasa nyaman dengan pekerjaannya, maka akan meningkatkan kualitas kehidupan kerjanya.

Penelitian ini, mendapatkan bahwa tingkat kualitas kehidupan kerja pada karyawan berada pada kategori tinggi. Kualitas kehidupan kerja yang cenderung positif ini mencerminkan bahwa karyawan memiliki persepsi yang cukup baik terhadap lingkungan perusahaan dan iklim organisasi yang dipengaruhi oleh apa danbagaimana timbal balik yang diperolehnya dari perusahaan. Hal itu diperkuat juga dari hasil wawancara dengan beberapa karyawan. Menurut mereka, perusahaan selalu berusaha memberikan kesempatan untuk belajar.Tidak hanya itu, perusahaan juga memperhatikan kesejahteraan dan memberikan keleluasaan bagikaryawan untuk membina paguyuban (kekeluargaan). Dalam penelitian ini, sumbangan efektif diberikan oleh iklim organisasi terhadap terciptanya kualitas kehidupan kerja karyawan.

Penelitian ini juga mendukung penelitian sebelumnya yang dilakukan Sudarnoto (2001). Penelitiannya membuktikan bahwa kondisi kualitas kehidupan kerja dapat tercipta apabila kebutuhan pekerjaan atas persyaratan pekerjaan, lingkungan pekerjaan, perilaku pemimpin serta praktek kerja yang memperhatikan kebutuhan personal pekerjaan telah terpenuhi.

Penelitian ini juga senada dengan penelitian yang dilakukan Dhar (2008), tentang kualitas kehidupan kerja. Penelitian yang berkaitan dengan kualitas kehidupan kerja dari supir bus dan faktor yang menyebabkan ketidakseimbangan, yang menyebabkan probabilitas tinggi kecelakaan di jalan. Sebuah studi kualitatif dilakukan dengan bantuan lima belas sopir bus dari empat depot bus yang berbeda Pune Municipal Corporation, India. Wawancara dilakukan secara mendalam dan melalui metode observasi naturalistik, untuk mengumpulkan data. Analisis data dilakukan melalui proses coding. Hasilnya menunjukkan bahwa kualitas kehidupan kerja tidak hanya harus diteliti dalam hal inisiatif yang dirancang untuk meningkatkan kehidupan kerja bagi karyawan. Sebaliknya, ada faktor potensial yang dapat berdampak pada kualitas kehidupan kerja untuk supir, yaitu tantangan yang mereka hadapi selama hari kerja dan kondisi di mana mereka bekerja. 


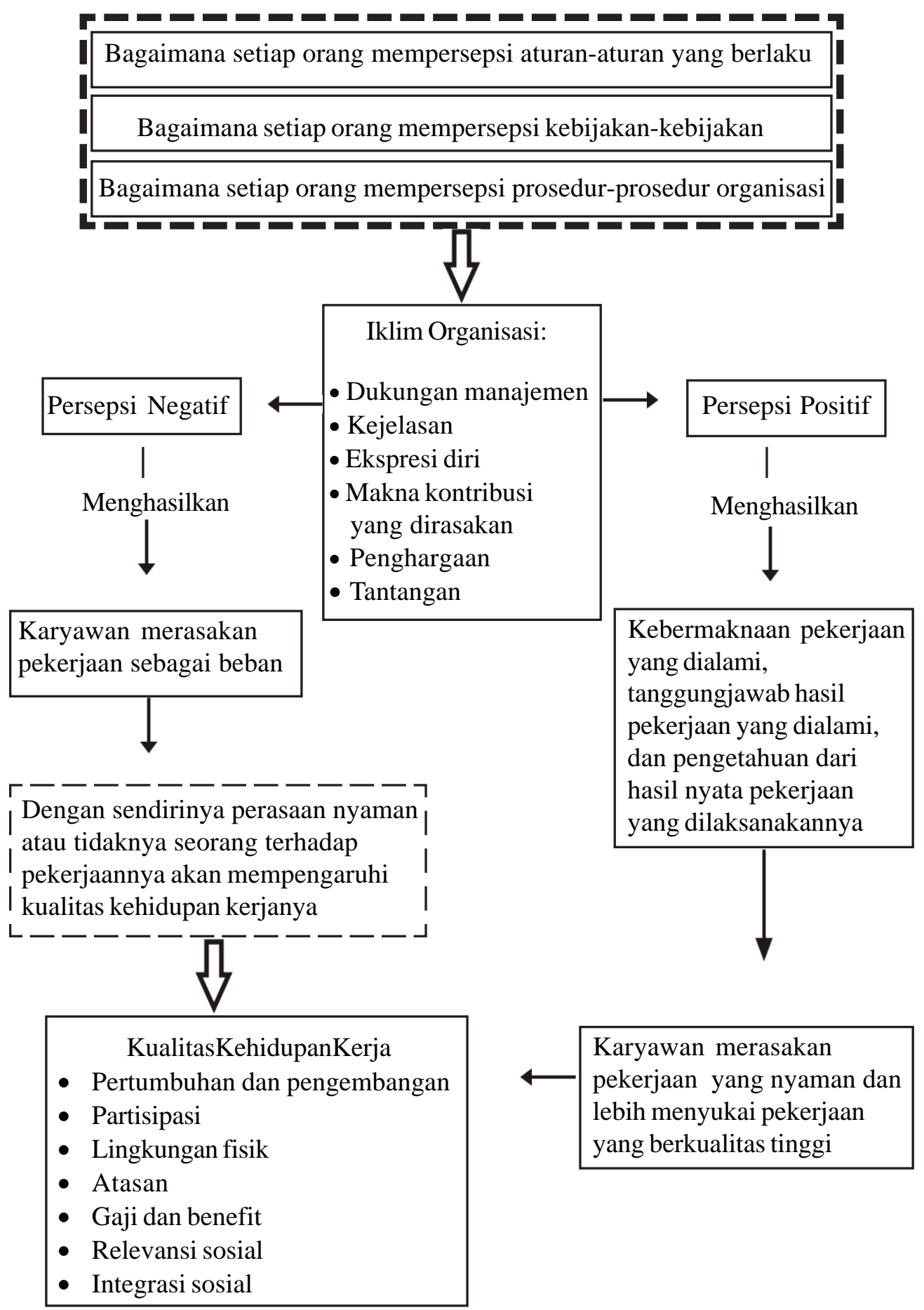

Gambar1

Dinamika hubungan iklim organisasi dan kualitas kehidupan kerja 
Begitu juga dengan penelitian yang dilakukan Deka(2011) yang menyatakan bahwa ada pengaruh iklim organisasi terhadap organisasi pembelajaran dan kualitas kehidupan kerja yaitu semakin tinggi iklim organisasi maka semakin tinggi pula organisasi pembelajaran dan kualitas kehidupan kerja karyawan. Dalam penelitiannya, iklim organisasi memberikan pengaruh sebesar 10,7 \% terhadap kualitas kehidupan kerja.

Berdasarkan hasil analisis regresi diketahui bahwa secara keseluruhan iklim organisasi memberikan kontribusi terhadap kualitas kehidupan kerjadengan $R$ square sebesar 0.484 atau $48,4 \%$, dengan demikian iklim organisasi memberikan kontribusi yang besar terhadap kualitas kehidupan kerja dengan sumbangan sebesar 48,4\%, sedangkan 51,6\% iklim organisasi dipengaruhi oleh faktor lainnya, misalnya kepemimpinan transformasional, persepsi karyawan terhadap kompensasi, kepuasan kerja, persepsi terhadap kinerja, dan stress kerja.

\section{Simpulan}

Kualitas kehidupan kerja dan iklim organisasi sangat penting karena hal tersebut berhubungan dengan hasil akhir positif organisasional yang lain. Faktor-faktor persepsi dalam iklim organisasi secara langsung dan tidak langsung merefleksikan praktekpraktek yang membuat karyawan memiliki kualitas kehidupan kerja dalam bekerjanya. Kondisi kerja yang buruk, pendapatan yang dinilai tidak memadai dan kurangnya otonomiserta kurangnya stabilitas kerja akan berakibat pada rendahnya kualitas kehidupan kerja seseorang.

\section{Daftar Pustaka}

Azwar, S. (2003). Penyusunan skala psikologi. Yogyakarta: Pustaka Pelajar.

Azwar, S. (2011). Reliabilitas dan validitas. Yogyakarta: Pustaka Pelajar.

Brown, P. S., \& Leigh, W.T. (1996). A new look at psychological climate and its relationship to job involvement, effort and performance. Journal of Applied Psychology, 81(4), 358-368.

Cascio, W. F., (1992). Managing human resources: Productivity, quality of work

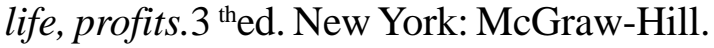

Dessler, G. (1992). Manajemen personalia teknik dan konsep modern (Penterjemah: Agus Dharma). Jakarta: Erlangga.

Dhar, R. L. (2008). Quality of work life: A study of municipal corporation bus drivers. The Journal of International Social Research, 1(5), 251-273. 
Deka, A. M. (2011). Pengaruh iklim organisasi terhadap organisasi pembelajaran dan kualitas kehidupan kerja. Tesis (tidak diterbitkan). Yogyakarta: Program Megister Psikologi Universitas Gadjah Mada.

Husnawati, A. (2006). Analisis pengaruh kualita skehidupan kerja terhadap kinerja karyawan dengan komitmen dan kepuasan kerja sebagai intervening variaebl. (Studi pada PERUM PegadaianKanwil VI Semarang). Tesis. Semarang: Program Studi Magister Manajemen Program Pasca Sarjana Universitas Diponegoro.

Idrus, M. (2006). Implikasi organisasi terhadap kepuasan kerja dan kualitas kehidupa kerja karyawan. Jurnal Psikologi Universitas Diponogoro, 3(1), 94-106.

Jewell, L.N., \& Siegall, M. (1998). Psikologi industri/organisasi modern: psikologi terapan untuk memecahkan berbagai masalah di tempatkerja, perusahaan, industri, dan organisasi.(edisi 2). Penerjemah: A. H. Pudjaatmaka \& Meitasari. Jakarta: Arcan.

Luthans, F. (2006). Perilaku organisasi. (Organizational behavior, 10th edition). Penerjemah: V. Andika dkk. Yogyakarta: Andi Offset.

Moorhead, G., \& Griffin, R.W. (1995). Organizational behavior managing people

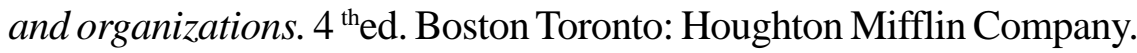

Riady,H. (2009). Meningkatkan komitmen karyawan atas organisasi melalui pengelolaan "quality of work life". Journal of Human Capital, 1(2), 119-13.

Riggio, R. E. (1990). Introduction to industrial/organizational psychology. New Jersey: Prentice Hall, inc.

Sudarnoto, L. F. N. (2001). Faktor-faktor pendukung kualita skehidupan kerja. Disertasi (Tidakditerbitkan). Yogyakarta: Program Psikologi Universitas Gadjah Mada.

Suryabrata, S. (2005). Alat ukur psikologis. Yogyakarta: Penerbit Andi.

Werther, W. B., \& Davis, K. (1996). Human resources and personnel management. Fifth edition.USA: McGraw-Hill.

Wirawan. (2008). Budaya dan iklim organisasi. Jakarta: Salemba Empat.

Zin, R.M. (2004). Perception of professional engineers toward quality of work life and organizational commitment a case study. Gadjah Mada International Journal of Business, 6(3), 323-334. 